\title{
Nocardioides nitrophenolicus sp. nov., a p-nitrophenol-degrading bacterium
}

\author{
Jung-Hoon Yoon, ${ }^{1,2}$ Young-Gyun Cho, ${ }^{2}$ Sung Taik Lee, ${ }^{2}$ \\ Ken-ichiro Suzuki, ${ }^{3}$ Takashi Nakase ${ }^{3}$ and Yong-Ha Park ${ }^{1}$
}

\author{
Author for correspondence: Yong-Ha Park. Tel: +82428604620 . Fax: +82428604625 . \\ e-mail: yhpark@kribb4680.kribb.re.kr
}

\footnotetext{
1 Korean Collection for Type Cultures (KCTC), Korea Research Institute of Bioscience and Biotechnology (KRIBB), PO Box 115, Yusong, Taejon, Korea

2 Department of Biological Sciences, Korea Advanced Institute of Science and Technology, Taejon, Korea

3 Japan Collection of Microorganisms, The Institute of Physical and Chemical Research (RIKEN), Wako-shi, Saitama 351-01, Japan
}

\begin{abstract}
A p-nitrophenol-degrading bacterial strain was isolated from industrial wastewater. This strain (NSP41T) was identified as a member of the genus Nocardioides from chemotaxonomic characterizations and phylogenetic inference based on 165 rDNA sequence analysis. The $G+C$ content is $71.4 \mathrm{~mol} \%$. The diamino acid in the cell-wall peptidoglycan is LL-diaminopimelic acid. The predominant menaquinone is $\mathrm{MK}-8\left(\mathrm{H}_{4}\right)$. The cellular fatty acid profile is similar to those of Nocardioides species. 165 rDNA sequence analysis show that strain NSP41 ${ }^{\top}$ is the most related to Nocardioides simplex strains with a level of nucleotide similarity of $98.6 \%$. The levels of 165 rDNA similarity between strain NSP41' and other Nocardioides species ranged from 93.8 to $95.1 \%$. This organism is distinguishable from some other Nocardioides species as well as $\mathbf{N}$. simplex strains by DNA-DNA relatedness data. This organism is different from $N$. simplex strains in some phenotypic characteristics. Therefore, on the basis of the data presented, a new species of the genus Nocardioides, Nocardioides nitrophenolicus, is proposed. The type strain of the new species is strain NSP41' ( = KCTC 0457BPT).
\end{abstract}

Keywords: Nocardioides nitrophenolicus, p-nitrophenol degradation

\section{INTRODUCTION}

Biotechnologically important Nocardioides species have been described previously (Arima et al., 1969; Gundersen \& Jensen, 1956; Yoon et al., 1997), and recently we isolated a Nocardioides-like isolate (strain NSP41 ${ }^{\mathrm{T}}$ ) which simultaneously degrades phenol and $p$-nitrophenol. From 16S rDNA sequence analysis (Yoon et al., 1998a), a strain, NSP41 ${ }^{\mathrm{T}}$, was shown to be the most related to Nocardioides simplex strains by its nucleotide similarity of $98.6 \%$. However, all of the strains that have been identified as $N$. simplex showed identical $16 \mathrm{~S}$ rDNA sequences. Recently, $16 \mathrm{~S}$ to $23 \mathrm{~S}$ rDNA internally transcribed spacer (16S-23S ITS) sequence analysis showed that strain NSP41 ${ }^{\mathrm{T}}$ was distinguished from $N$. simplex strains in length and sequence variability of $16 \mathrm{~S}-23 \mathrm{~S}$ ITS. The $16 \mathrm{~S}-23 \mathrm{~S}$ ITS of strain NSP41 $1^{\mathrm{T}}$ was $328 \mathrm{bp}$ long, whereas the 16S-23S ITSs of $N$. simplex strains were 386 to $388 \mathrm{bp}$ long. Strain NSP41 $1^{\mathrm{T}}$ exhibited levels of $16 \mathrm{~S}-23 \mathrm{~S}$ ITS

Abbreviations: FAME, fatty acid methyl ester; ITS, internally transcribed spacer.

The GenBank accession number for the $16 \mathrm{~S}$ rDNA sequence of strain NSP41 ${ }^{\top}$ is AF005024. similarity of $81 \cdot 8-84 \cdot 6 \%$ and levels of $16 \mathrm{~S}-23 \mathrm{~S}$ ITS similarity with gaps included of $68.4-70 \cdot 1 \%$ with $N$. simplex, whereas the levels of 16S-23S ITS similarity between $N$. simplex strains ranged from $97.7 \%$ to $100 \%$. Strain NSP 41 's ability to degrade $p$-nitrophenol was not found in $N$. simplex strains. Therefore, it was necessary to determine the exact taxonomic position of strain NSP $41^{\mathrm{T}}$ through detailed taxonomic study. On the basis of data described below, we propose that this strain (NSP41 ${ }^{\mathrm{T}}$ ) should be placed in the genus $\mathrm{No}$ cardioides as a new species, Nocardioides nitrophenolicus.

\section{METHODS}

Bacterial strain and culture conditions. Strain NSP41 ${ }^{\mathrm{T}}$ was isolated from an industrial wastewater. The wastewater samples were inoculated in $50 \mathrm{ml}$ minimal salts medium (Yoon et al., 1997) containing $\left(1^{-1}\right) 1 \mathrm{~g} \mathrm{~K}_{2} \mathrm{HPO}_{4}, 0.5 \mathrm{~g}$ $\mathrm{NaH}_{2} \mathrm{PO}_{4} .2 \mathrm{H}_{2} \mathrm{O}, 0.25 \mathrm{~g} \mathrm{KCl}, 0.25 \mathrm{~g} \mathrm{MgSO}_{4} .7 \mathrm{H}_{2} \mathrm{O}, 1 \mathrm{ml}$ trace element solution (Lee et al., 1991) supplemented with $100 \mathrm{mg} p$-nitrophenol $\mathrm{l}^{-1}$ and $15 \mathrm{~g}$ agar (if needed). This medium was incubated at $30^{\circ} \mathrm{C}$ on a horizontal shaker at 150 r.p.m. When the yellow colour of the medium disappeared, $5 \mathrm{ml}$ of the suspension was transferred into $50 \mathrm{ml}$ fresh medium. The suspension was plated on solid media 
containing $p$-nitrophenol in order to isolate pure cultures. Single colonies were tested to investigate the ability to utilize $p$-nitrophenol as a sole carbon and energy sources for growth. Among isolates, one strain, NSP41 ${ }^{\mathrm{T}}$, that showed high $p$-nitrophenol-degrading activity was selected for further studies.

For the investigation of morphological and physiological characteristics, strain NSP41 $1^{\mathrm{T}}$ was cultivated on nutrient agar (Difco) at $30^{\circ} \mathrm{C}$ for $36-48 \mathrm{~h}$. Cell mass for the analyses of cell wall and menaquinones was obtained from nutrient broth (Difco) culture at $30^{\circ} \mathrm{C}$. For fatty acids methyl ester (FAME) analysis, strain NSP41 ${ }^{\mathrm{T}}$ and reference strains also were grown for $4 \mathrm{~d}$ on nutrient agar (Difco). Reference strains for FAME analysis included Nocardioides albus KCTC $9186^{\mathrm{T}}$ ( $\mathrm{T}=$ Type strain), Nocardioides jensenii KCTC 9134 ${ }^{\mathrm{T}}$, Nocardioides luteus KCTC $9575^{\mathrm{T}}$, Nocardioides simplex strains KCTC 9106' , JCM 1366, JCM 1367, NCIMB 12919 and ATCC 15799, Aeromicrobium erythreum NRRL B-3381 ${ }^{\mathrm{T}}$ and Aeromicrobium fastidiosum KCTC $9576^{\mathrm{T}}$.

Morphological and physiological tests. The morphology of cells grown was examined by light microscopy. Motility was determined with an optical microscope using the hanging drop technique (Skerman, 1967). Flagellum type was examined with transmission electron microscopy using cells from the exponential phase of growth. The cells were negatively stained with $1 \%(\mathrm{w} / \mathrm{v})$ phosphotungstic acid, and after air-drying the grids were examined by using a model CM-20 transmission electron microscope (Philips). Catalase activity was determined by bubble production in a $3 \%$ hydrogen peroxide solution. Oxidase activity was determined by oxidation of $1 \%$ tetramethyl-p-phenylenediamine. Hydrolyses of casein and starch, and production of urease were determined as described previously (Cowan \& Steel, 1965). Hydrolyses of aesculin and arbutin were determined according to the methods of Kurup \& Fink (1975). Hydrolysis of elastin was determined according to the method of Williams et al. (1983). Tests for utilization of various substrates as sole carbon and energy sources were performed as described previously (Shirling \& Gottlieb, 1966). Most of the substrates were tested at a concentration of $1 \%(\mathrm{w} / \mathrm{v})$; the exception was glycerol $(0 \cdot 1 \%, w / v)$. The utilization results were checked over a period of 4 weeks.

Isolation of DNA. Chromosomal DNA was isolated and purified according to the method described previously (Yoon et al., 1996).

Chemotaxonomic characterizations. The diamino acid of the peptidoglycan was determined by the method described previously (Komagata \& Suzuki, 1987). Menaquinones were analysed as described previously (Komagata \& Suzuki, 1987) using reversed-phase HPLC. Fatty acids were extracted and analysed according to the instructions of the Microbial Identification System (MIDI).

Determination of $\mathbf{G}+\mathbf{C}$ content. The $\mathrm{G}+\mathrm{C}$ content was determined by the method of Tamaoka \& Komagata (1984). DNA was hydrolysed and dephosphorylated, and the resultant nucleosides were analysed by reversed-phase HPLC.

Phylogenetic analysis based on 165 rDNA sequences. The determination of $16 \mathrm{~S}$ rDNA sequence was described previously (Yoon et al., 1998a). The 16S rDNA sequence of strain NSP4 $1^{\mathrm{T}}$ was aligned with 16S rRNA gene sequences of Nocardioides species and some other actinomycete taxa by using CLUSTAL w software (Thompson et al., 1994). Other reference sequences were obtained from the GenBank database with the following accession numbers: Nocar- dioides albus KCTC 9186 ${ }^{\mathrm{T}}$ (AF004988), Nocardioides jensenii KCTC 9134 ${ }^{\mathrm{T}}$ (AF005006), Nocardioides luteus KCTC $9575^{\mathrm{T}}$ (AF005007), Nocardioides plantarum KCTC 9577 ${ }^{\mathrm{T}}$ (AF005008), Nocardioides simplex KCTC 9106 ${ }^{\mathrm{T}}$ (AF005009), Aeromicrobium erythreum NRRL B-3381 ${ }^{\mathrm{T}}$ (AF005021), Aeromicrobium fastidiosum KCTC 9576 ${ }^{\mathrm{T}}$ (AF005022), Terrabacter tumescens KCTC $9133^{\mathrm{T}}$ (AF005023), Microlunatus phosphovorus DSM 10555 ${ }^{\mathrm{T}}$ (Z78207), Luteococcus japonicus DSM 10546 ${ }^{\mathrm{T}}$ (Z78208), Friedmanniella antarctica

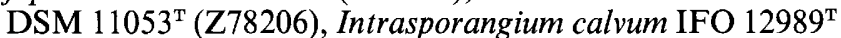
(D85486), Kineosporia aurantiaca ATCC $28727^{\mathrm{T}}$ (X87110), Terracoccus luteus DSM 44267 ${ }^{\mathrm{T}}$ (Y11928), Sporichthya polymorpha DSM 46113 (X72377), Propionibacterium freudenreichii DSM 20271 ${ }^{\mathrm{T}}$ (X53217), Propionibacterium acnes DSM 1897 ${ }^{\mathrm{T}}$ (X53218), Streptomyces albus DSM $40313^{\mathrm{T}}$ (X53163), Arthrobacter globiformis DSM 20124 (M23411), Micrococcus luteus ATCC 381 (M38242), Rhodococcus rhodochrous strain 116 (Karlson et al., 1993) (X70295), Nocardia asteroides ATCC 19247 ${ }^{\mathrm{T}}$ (Z36934) and Sphaerobacter thermophilus DSM 20745 ${ }^{\mathrm{T}}$ (X53210). The 16S

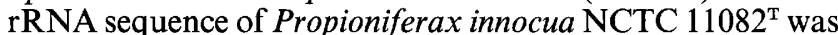
obtained from the study of Pitcher \& Collins (1991). The 16S rDNA similarity values were calculated from the alignment and the evolutionary distances were calculated by using Kimura two-parameter correction with CLUSTAL w software. A phylogenetic tree was constructed by using the neighbourjoining method (Saitou \& Nei, 1987) on the basis of distance matrix data. A bootstrap analysis with 1000 replications for evaluating the topology of phylogenetic tree was performed with CLUSTAL W.

DNA-DNA relatedness test. $N$. albus KCTC $9186^{\mathrm{T}}$, $N$. jensenii KCTC $9134^{\mathrm{T}}, N$. luteus $\mathrm{KCTC} 9575^{\mathrm{T}}, N$. simplex strains KCTC 9106 ${ }^{\mathrm{T}}$, JCM 1366, JCM 1367, NCIMB 12919 and ATCC 15799 were used as reference strains for DNA-DNA hybridization. DNA-DNA hybridization to determine genomic relatedness was performed by dot-blot hybridization method. Labelling of probe and visualization of hybridized DNA were performed by using a non-radioactive ECL direct nucleic acid labelling and detection system (Amersham International). Resultant quantitative DNADNA relatedness was determined by using a densitometer (Bio-Rad).

\section{RESULTS}

\section{Morphological and physiological characteristics}

Strain NSP41 ${ }^{\mathrm{T}}$ is aerobic, non-spore-forming, nonacid-fast and motile, and it is Gram-positive but Gramvariable in old cultures. After $2 \mathrm{~d}$ cultivation on nutrient agar, single cells are rod-shaped that are $0.5-0.8 \mu \mathrm{m}$ wide by $1.0-3.0 \mu \mathrm{m}$ long (Fig. 1). Single cells bear a single polar flagellum (Fig. 1), whereas $N$. simplex strains KCTC $9106^{\mathrm{T}}$, JCM 1366 and JCM 1367 are known to bear peritrichous flagella (Suzuki \& Komagata, 1983). Single cells show a coccoid form in old cultures. The cells exhibit rod-coccus morphogenesis from the early-exponential phase to the stationary phase. The colonial morphology is nearly identical with that of type strain of $N$. simplex on nutrient agar. Colonies are smooth, glossy and yellowish white with irregular edges on nutrient agar. Neither substrate mycelium nor primary mycelium is formed. Strain NSP $41^{\mathrm{T}}$ grew at $\mathrm{pH} 6$ and 10 , but it did not grow at pH 5. Strain NSP $41^{\mathrm{T}}$ grew at 20 and $40^{\circ} \mathrm{C}$ 


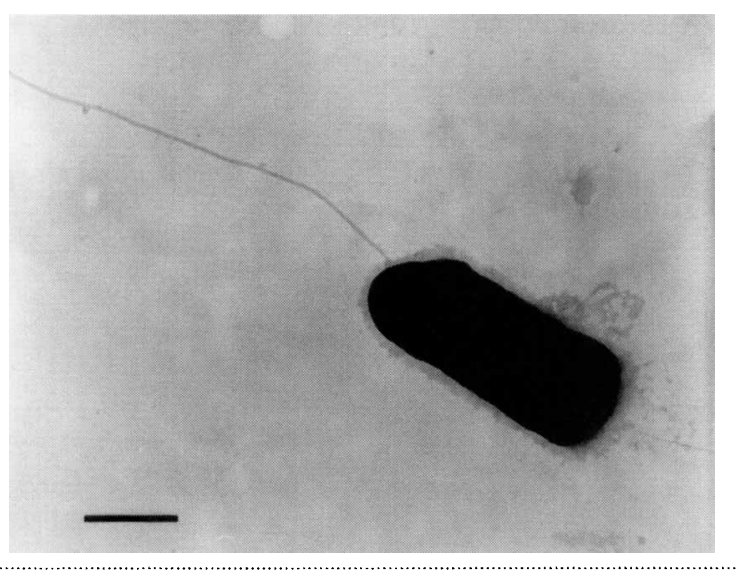

Fig. 1. Transmission electron micrograph of strain NSP41 grown on nutrient agar for $48 \mathrm{~h}$ at $30^{\circ} \mathrm{C}$. Bar, $0.5 \mu \mathrm{m}$.

and weakly at $15^{\circ} \mathrm{C}$, but it did not grow at $45^{\circ} \mathrm{C}$. The optimal $\mathrm{pH}$ and temperature for growth were 8 and $30^{\circ} \mathrm{C}$, respectively. Some other physiological properties of strain NSP41 ${ }^{\mathrm{T}}$ are represented in Table 1, together with those of $N$. simplex strains.

\section{Chemotaxonomic characteristics and DNA base composition}

Strain NSP $41^{\mathrm{T}}$ had cell-wall peptidoglycan based on LL-diaminopimelic acid as the diamino acid. Tetrahydrogenated menaquinone with eight isoprenoid units $\left[\mathrm{MK}-8\left(\mathrm{H}_{4}\right)\right]$ was predominant in strain NSP41 ${ }^{\mathrm{T}}$. The major fatty acids were iso- $\mathrm{C}_{16: 0}$ and 10-methylbranched fatty acids, which are characteristically found as major components in the genus Nocardioides
(Table 2). Strain NSP41 ${ }^{\mathrm{T}}$ also had relatively high proportions of iso- $\mathrm{C}_{17: 0}$ and anteiso- $\mathrm{C}_{17: 0}$ when compared to $N$. simplex strains and other Nocardioides species (Table 2).

The genomic DNA G + C content of strain NSP $41^{\mathrm{T}}$ was $71.4 \mathrm{~mol} \%$. Nocardioides species are known to have genomic DNA $\mathrm{G}+\mathrm{C}$ content ranging from $66.5 \mathrm{~mol} \%$ (N. albus) to $73.0 \mathrm{~mol} \%$ (N. simplex).

\section{Phylogenetic analysis}

The phylogenetic inference based on 16S rDNA sequence of strain NSP41 ${ }^{\mathrm{T}}$ were performed in a previous study. Strain NSP $41^{\mathrm{T}}$ formed a phylogenetic lineage within the cluster enclosed by the genus Nocardioides, and is phylogenetically related to $N$. simplex. The cluster of strain NSP $41^{\mathrm{T}}$ and $N$. simplex was supported by $100 \%$ in bootstrap analysis (Fig. 2). Strain NSP $41^{\mathrm{T}}$ exhibited levels of $16 \mathrm{~S}$ rDNA similarity of $98.6 \%$ to $N$. simplex strains and levels of $16 \mathrm{~S} \mathrm{rDNA}$ similarity of 93.8 to $95.1 \%$ to the type strains of other validly described Nocardioides species except $N$. simplex.

\section{DNA-DNA relatedness test}

Strain NSP $41^{\mathrm{T}}$ exhibited levels of DNA-DNA relatedness of $41 \%$ to the type strain of $N$. simplex and of $35-43 \%$ to other $N$. simplex strains, whereas the type strain of $N$. simplex exhibited levels of DNA-DNA relatedness of $85-103 \%$ to other strains of $N$. simplex. Strain NSP $41^{\mathrm{T}}$ also exhibited levels of DNA-DNA relatedness of 27,38 and $36 \%$, to $N$. albus KCTC $9186^{\mathrm{T}}, N$. jensenii KCTC $9134^{\mathrm{T}}$ and $N$. plantarum NCIMB $12834^{\mathrm{T}}$, respectively.

\section{Table 1. Physiological characteristics of $N$. simplex strains and strain NSP41 ${ }^{\top}$}

+ , Positive reaction; - , negative reaction; w, weakly positive reaction. All strains were positive for oxidase, catalase, hydrolysis of aesculin, starch and Tween 80 , utilization of $(+)$-D-glucose, sucrose, $(-)$-D-trehalose, disodium fumarate and disodium succinate as sole carbon and energy source. All strains were negative for hydrolysis of elastin, utilization of L-arabinose, $(+)$-Dgalactose, (+)-D-cellobiose, lactose, maltose, melezitose, $\alpha$-D-melibiose, (+)-D-raffinose, adonitol, myo-inositol, D-mannitol, Dsorbitol, inulin, glycerol, CM-cellulose, trisodium citrate and sodium citrate as sole carbon and energy source.

\begin{tabular}{|c|c|c|c|c|c|c|}
\hline Character & KCTC $9106^{\mathrm{T}}$ & JCM 1366 & JCM 1367 & NCIMB 12919 & ATCC 15799 & NSP41 ${ }^{\mathrm{T}}$ \\
\hline \multicolumn{7}{|l|}{ Hydrolysis of: } \\
\hline Arbutin & - & - & - & $\mathrm{w}$ & - & w \\
\hline Casein & + & + & + & w & + & + \\
\hline Urea & - & - & - & - & - & + \\
\hline \multicolumn{7}{|l|}{$\begin{array}{l}\text { Utilization of as sole } \\
\text { carbon and energy } \\
\text { source: }\end{array}$} \\
\hline (-)-D-Ribose & w & - & - & - & w & + \\
\hline$(+)$-D-Xylose & - & - & - & - & - & + \\
\hline (-)-D-Fructose & - & - & - & - & - & + \\
\hline$(+)$-D-Mannose & - & - & - & - & - & w \\
\hline$\alpha-(+)$-L-Rhamnose & - & - & - & - & - & + \\
\hline Sodium acetate & $\therefore$ & + & + & - & - & + \\
\hline
\end{tabular}


Table 2. Cellular fatty acid profiles of representatives of the genus Nocardioides, Nocardioides sp. strain NSP41 and Aeromicrobium species

Strains: 1, Nocardioides albus KCTC $9186^{\mathrm{T}} ; 2$, Nocardioides jensenii $\mathrm{KCTC} 9134^{\mathrm{T}} ; 3$, Nocardioides luteus $\mathrm{KCTC} 9575^{\mathrm{T}} ; 4$,

Nocardioides simplex strains KCTC 9106 ; 5, JCM 1366; 6, JCM 1367; 7, NCIMB 12919; 8, ATCC 15799; 9, Nocardioides sp.

NSP41; 10, Aeromicrobium erythreum NRRL B-3381 $; 11$, Aeromicrobium fastidiosum KCTC $9576^{\mathrm{T}}$.

\begin{tabular}{|c|c|c|c|c|c|c|c|c|c|c|c|}
\hline \multirow[t]{2}{*}{ Fatty acid } & \multicolumn{11}{|c|}{ Strain } \\
\hline & 1 & 2 & 3 & 4 & 5 & 6 & 7 & 8 & 9 & 10 & 11 \\
\hline \multicolumn{12}{|c|}{ Saturated fatty acids } \\
\hline $\mathrm{C}_{14 \cdot 0}$ & & & & & & & & & & 0.7 & $0 \cdot 6$ \\
\hline$C_{15: 0}$ & 0.7 & $0 \cdot 3$ & & & & & & & & $1 \cdot 7$ & $1 \cdot 0$ \\
\hline$C_{16: 0}^{10.0}$ & 0.7 & $1 \cdot 3$ & 0.6 & $1 \cdot 1$ & $1 \cdot 4$ & $2 \cdot 0$ & $2 \cdot 0$ & $1 \cdot 1$ & $2 \cdot 3$ & $20 \cdot 0$ & $10 \cdot 1$ \\
\hline$C_{17: 0}$ & 1.5 & $2 \cdot 7$ & 0.5 & & $1 \cdot 1$ & 0.9 & 0.6 & & 0.9 & $2 \cdot 4$ & $2 \cdot 1$ \\
\hline$C_{18: 0}$ & & $2 \cdot 0$ & & $1 \cdot 3$ & $2 \cdot 6$ & $2 \cdot 9$ & $3 \cdot 0$ & 0.9 & & $6 \cdot 1$ & $9 \cdot 7$ \\
\hline \multicolumn{12}{|l|}{$C_{19: 0}^{180}$} \\
\hline \multicolumn{12}{|l|}{$\mathrm{C}_{20: 0}$} \\
\hline \multicolumn{12}{|c|}{ Unsaturated fatty acids } \\
\hline$C_{15.1} \omega 6 c$ & & $0 \cdot 3$ & & & & & & & & & \\
\hline $\mathrm{C}_{16: 1}^{10.1} \omega 9 c$ & & & & & & & & & & 0.8 & 1.4 \\
\hline $\mathrm{C}_{17: 1} \omega 6 c$ & $15 \cdot 6$ & $5 \cdot 2$ & 15.9 & $13 \cdot 1$ & $14 \cdot 5$ & 11.9 & $13 \cdot 4$ & $14 \cdot 8$ & $10 \cdot 8$ & $0 \cdot 6$ & \\
\hline $\mathrm{C}_{17: 1} \omega 8 c$ & $2 \cdot 8$ & $3 \cdot 4$ & $1 \cdot 1$ & $2 \cdot 3$ & $2 \cdot 7$ & $2 \cdot 3$ & $1 \cdot 3$ & $3 \cdot 6$ & $1 \cdot 4$ & 0.8 & \\
\hline $\mathrm{C}_{17: 1} \omega 9 c$ & & & & & & & & & & & $0 \cdot 9$ \\
\hline $\mathrm{C}_{18: 1} \omega 9 c$ & & $3 \cdot 3$ & & $7 \cdot 3$ & $12 \cdot 0$ & $9 \cdot 2$ & $8 \cdot 5$ & $7 \cdot 9$ & $4 \cdot 5$ & $25 \cdot 6$ & $25 \cdot 1$ \\
\hline$C_{19: 1}^{10.1}$ iso $I^{*}$ & & & & $1 \cdot 6$ & & & & $1 \cdot 1$ & & & \\
\hline \multicolumn{12}{|c|}{ Branched-chain fatty acids } \\
\hline iso- $\mathrm{C}_{13: 0}$ & & & & & $0 \cdot 3$ & & & & & & \\
\hline iso- $\mathrm{C}_{14: 0}$ & $2 \cdot 2$ & $1 \cdot 1$ & 0.7 & $1 \cdot 6$ & $0 \cdot 4$ & 0.6 & 0.6 & $1 \cdot 4$ & $0 \cdot 4$ & & \\
\hline iso- $\mathrm{C}_{14: 0} 3-\mathrm{OH}$ & & & 0.6 & & & & & & & & \\
\hline iso- $\mathrm{C}_{15: 0}$ & $3 \cdot 1$ & $3 \cdot 7$ & 3.7 & $1 \cdot 5$ & 1.6 & $1 \cdot 7$ & $2 \cdot 1$ & $1 \cdot 6$ & $3 \cdot 1$ & & \\
\hline anteiso- $\mathrm{C}_{15: 0}$ & & & & & & & & & 0.5 & & \\
\hline iso- $\mathrm{C}_{16: 1} \mathrm{H}^{*}$ & $1 \cdot 1$ & $14 \cdot 0$ & $2 \cdot 1$ & $5 \cdot 4$ & $2 \cdot 8$ & $2 \cdot 8$ & $3 \cdot 3$ & 6.6 & $1 \cdot 3$ & & \\
\hline iso- $\mathrm{C}_{16: 0}$ & $53 \cdot 6$ & $45 \cdot 5$ & $49 \cdot 1$ & $33 \cdot 7$ & $29 \cdot 0$ & $36 \cdot 6$ & $32 \cdot 3$ & $30 \cdot 5$ & $28 \cdot 1$ & $1 \cdot 4$ & \\
\hline iso- $\mathrm{C}_{17: 0}$ & $1 \cdot 3$ & $1 \cdot 7$ & $1 \cdot 0$ & $2 \cdot 2$ & $6 \cdot 1$ & $6 \cdot 4$ & $5 \cdot 4$ & $2 \cdot 2$ & $12 \cdot 3$ & & \\
\hline iso- $\mathrm{C}_{17: 1} \omega 9 c$ & & & & & & & & & & 0.4 & 0.7 \\
\hline anteiso- $\mathrm{C}_{17: 1} \omega 9 c$ & & & & & & & & & & & \\
\hline anteiso- $\mathrm{C}_{17: 0}$ & $0 \cdot 7$ & 0.7 & $1 \cdot 4$ & 0.5 & 0.8 & 1.5 & $1 \cdot 0$ & & 5.8 & & \\
\hline iso- $\mathrm{C}_{18: 0}$ & 0.9 & $2 \cdot 7$ & & 0.9 & $4 \cdot 0$ & $3 \cdot 4$ & $3 \cdot 8$ & 0.8 & 1.6 & 0.5 & \\
\hline \multicolumn{12}{|c|}{ 10-Methyl fatty acids } \\
\hline$C_{16: 0}$ & 1.5 & $2 \cdot 5$ & $5 \cdot 0$ & $4 \cdot 0$ & $1 \cdot 1$ & $1 \cdot 2$ & $1 \cdot 3$ & $4 \cdot 2$ & $3 \cdot 6$ & & \\
\hline $\mathrm{C}_{17: 0}$ & $12 \cdot 2$ & $5 \cdot 4$ & $15 \cdot 0$ & 5.4 & 3.6 & $2 \cdot 6$ & $2 \cdot 4$ & $6 \cdot 3$ & $5 \cdot 1$ & $0 \cdot 3$ & \\
\hline $\mathrm{C}_{18: 0}$ & $2 \cdot 3$ & $2 \cdot 4$ & $2 \cdot 9$ & $9 \cdot 3$ & $12 \cdot 7$ & $10 \cdot 0$ & $15 \cdot 3$ & $10 \cdot 3$ & $13 \cdot 9$ & $24 \cdot 2$ & $32 \cdot 9$ \\
\hline \multicolumn{12}{|c|}{ Hydroxy fatty acids } \\
\hline $\mathrm{C}_{15: 0} 2-\mathrm{OH}$ & & & & & & & & & & 0.6 & $0 \cdot 6$ \\
\hline $\mathrm{C}_{16: 0} 2-\mathrm{OH}$ & & & & $0 \cdot 7$ & 0.5 & $0 \cdot 4$ & 0.5 & $1 \cdot 0$ & 0.7 & $11 \cdot 3$ & 8.9 \\
\hline $\mathrm{C}_{17: 0} 2-\mathrm{OH}$ & & & & & & & & & 0.4 & $0 \cdot 9$ & $1 \cdot 5$ \\
\hline $\mathrm{C}_{18: 0} 2-\mathrm{OH}$ & & & & & & & & & & $1 \cdot 1$ & $3 \cdot 7$ \\
\hline \multicolumn{12}{|l|}{ Summed features $\dagger$} \\
\hline 4 & & $1 \cdot 2$ & & $5 \cdot 1$ & 1.6 & 1.9 & $2 \cdot 0$ & $3 \cdot 7$ & 1.8 & & 0.9 \\
\hline 5 & & & & & & & & & & & \\
\hline 6 & & & & 0.7 & & $0 \cdot 3$ & $0 \cdot 3$ & 0.5 & $0 \cdot 4$ & & \\
\hline 7 & & & & $2 \cdot 4$ & 0.8 & $1 \cdot 2$ & 0.9 & 1.7 & 0.9 & & \\
\hline 8 & & & & & 0.5 & $0 \cdot 3$ & & & $0 \cdot 4$ & & \\
\hline
\end{tabular}

* The double bond position indicated by an upper-case letter is unknown.

† Summed features represent groups of two or three fatty acids which could not be separated by GLC with the MIDI system. Summed feature 4 contained one or more of following fatty acids: $15: 0$ iso $2-\mathrm{OH}$ and/or $16: 1 \omega 7 \mathrm{c}$. Summed feature 6 contained one or more of following fatty acids : $18: 0$ anteiso and/or 18:2 $\omega 6,9 \mathrm{c}$. Summed feature 7 contained one or more of following fatty acids: $18: 1 \omega 7 \mathrm{c}$, 18: $1 \omega 9 t$ and/or $18: 1 \omega 12 t$. Summed feature 8 contained one or more of following fatty acids: unknown 18.756 and/or $19: 1 \omega 11 \mathrm{c}$. 


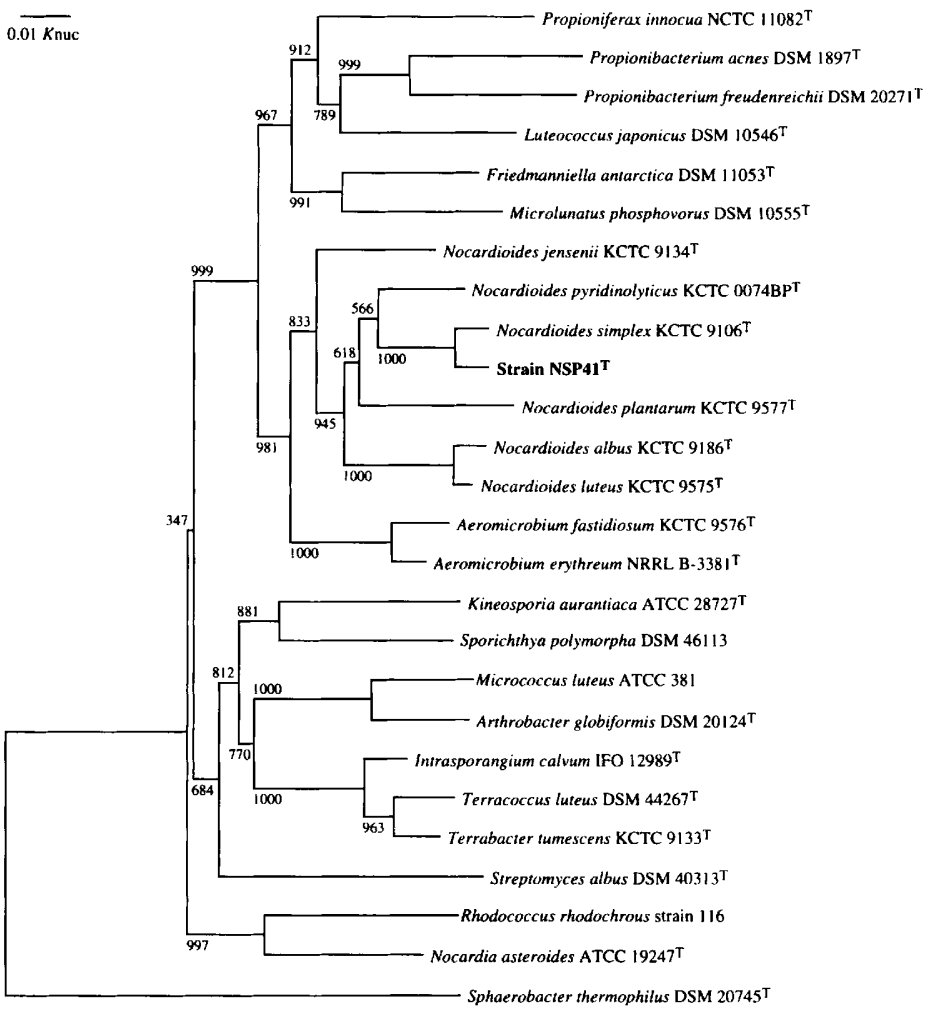

Fig. 2. Phylogenetic tree based on $16 \mathrm{~S}$ rDNA sequences showing the position of strain NSP4 ${ }^{\top}$, other representatives of the genus Nocardioides and some other actinomycete taxa.

\section{DISCUSSION}

The chemotaxonomic properties of strain $\mathrm{NSP} 41^{\mathrm{T}}$ were compared with those of LL-diaminopimelic acidcontaining actinomycete taxa. The comparison showed that strain NSP41 ${ }^{\mathrm{T}}$ has characteristics that are consistent with the genus Nocardioides in menaquinone composition and fatty acid profiles (Tamura \& Yokota, 1994). Therefore, strain NSP41 ${ }^{\mathrm{T}}$ was considered to be a member of the genus Nocardioides. From phylogenetic inference based on 16S rDNA sequences, strain $\mathrm{NSP} 41^{\mathrm{T}}$ was considered as being related to $N$. simplex (Fig. 2). However, N. simplex did not exhibit intraspecific variation in $16 \mathrm{~S}$ rDNA sequence, that is, $N$. simplex strains KCTC $9106^{\mathrm{T}}$, JCM 1366, JCM 1367, NCIMB 12919 and ATCC 39419 were found to have identical 16S rDNA sequences, whereas strain NSP41 $1^{\mathrm{T}}$ exhibited a level of $16 \mathrm{~S}$ rDNA similarity of $98.6 \%$ to $N$. simplex strains (Yoon et al., 1998a). The 16S-23S ITS sequence analysis also encouraged us to investigate the taxonomic position of strain NSP41 ${ }^{\mathrm{T}}$ in detail (Yoon et al., 1998b).

Strain NSP $41^{\mathrm{T}}$ formed a cluster with $N$. simplex by $100 \%$ recovery in the bootstrap analysis (Fig. 2). Therefore, strain NSP $41^{\mathrm{T}}$ was mainly compared with $N$. simplex strains in some taxonomic properties. Some physiological characteristics and flagellum type of strain NSP $41^{\mathrm{T}}$ differed from those of $N$. simplex strains (Table 1). In particular, strain NSP4 $1^{\mathbf{T}}$ has the ability to degrade $p$-nitrophenol which is not found in $N$. simplex strains. Strain NSP $41^{\mathbf{T}}$ was found to degrade up to $200 \mathrm{mg} p$-nitrophenol $\mathrm{l}^{-1}$, whereas $N$. simplex strains could not degrade even minimum concentrations of $p$-nitrophenol. The fatty acid profile of strain NSP41 ${ }^{\mathrm{T}}$ showed differences from other $\mathrm{No}$ cardioides species as well as $N$. simplex strains in the composition of iso- $\mathrm{C}_{17: 0}$ and anteiso- $\mathrm{C}_{17: 0}$ (Table 2). It has been already pointed out that strain NSP41 ${ }^{\mathrm{T}}$ is distinguished from $N$. simplex strains in length and sequence variability of the $16 \mathrm{~S}-23 \mathrm{~S}$ ITS region (Yoon et al., 1998b). DNA-DNA relatedness provides final evidence that strain NSP4 $1^{\mathrm{T}}$ is a new species of the genus Nocardioides, since it has been recognized as an important criterion for defining species in current bacteriology (Wayne et al., 1987). There is general agreement that a level of DNA-DNA relatedness of $70 \%$ is the threshold value for defining species.

On the basis of the data described above, we propose a new species, Nocardioides nitrophenolicus, for strain NSP $41^{\mathrm{T}}$. The properties of the species are summarized below.

\section{Description of Nocardioides nitrophenolicus sp. nov.}

Nocardioides nitrophenolicus (ni.tro.phen.o'li.cus. L. masc. adj. nitro containing nitrogen; N.L. n. pheno phenol; L. fem. adj. nitrophenolicus relating to nitrophenols).

Cells are aerobic, non-acid-fast, non-spore-forming 
rods that are $0.5-0.8 \mu \mathrm{m}$ wide and $1 \cdot 0-3.0 \mu \mathrm{m}$ long in $2 \mathrm{~d}$ culture on nutrient agar. Cells exhibit coccoid morphology in the stationary phase of growth. Grampositive but Gram-variable in old cultures. Motile by means of a single polar flagellum. Colonies are smooth, glossy and yellowish white with irregular edges on nutrient agar. Neither substrate mycelium nor primary mycelium is formed. Growth occurs at $\mathrm{pH} 6$ and 10 and at 15 and $40{ }^{\circ} \mathrm{C}$. Optimal $\mathrm{pH}$ and temperature for growth are 8 and $30^{\circ} \mathrm{C}$, respectively. Catalase- and oxidase-positive. Casein, aesculin, starch, Tween 80 and urea are hydrolysed. Arbutin is weakly hydrolysed. Elastin is not hydrolysed. D-Ribose, D-xylose, Dfructose, D-glucose, D-mannose, L-rhamnose, sucrose, D-trehalose, disodium fumarate, disodium succinate and sodium acetate are utilized as sole carbon and energy sources for growth. L-Arabinose, D-galactose, D-mannose, D-cellobiose, lactose, maltose, melezitose, D-melibiose, D-raffinose, adonitol, myo-inositol, Dmannitol, D-sorbitol, inulin, glycerol, carboxymethyl cellulose, trisodium citrate and sodium benzoate are not utilized. Degrades phenol and $p$-nitrophenol. The $\mathrm{G}+\mathrm{C}$ content is $71.4 \mathrm{~mol} \%$ (as determined by HPLC). Isolated from industrial wastewater in Cheong-ju, Korea. The type strain is strain NSP41 ${ }^{\mathrm{T}}$, which has been deposited in the Korean Collection for Type Cultures as KCTC 0457 $\mathrm{BP}^{\mathrm{T}}$.

\section{ACKNOWLEDGEMENTS}

This work was supported by Asian Network on Microbial Researches from the Science and Technology Agency of Japan and grant HS1841 from the Ministry of Science and Technology of the Republic of Korea. We are grateful to Dr Yong Kook Shin for helpful discussion, Jung-Sook Lee for analysing DNA base composition and to J. L. Swezey of the ARS Patent Culture Collection, Microbial Properties Research, for providing Aeromicrobium erythreum NRRL B$3381^{\mathrm{T}}$.

\section{REFERENCES}

Arima, K., Nagasawa, M., Bae, M. \& Tamura, G. (1969). Microbial transformation of sterols. I. Decomposition of cholesterol by microorganisms. Agric Biol Chem 33, 1636-1643.

Cowan, S. T. \& Steel, K. J. (1965). Manual for the Identification of Medical Bacteria. London: Cambridge University Press.

Gundersen, K. \& Jensen, H. L. (1956). A soil bacterium decomposing organic nitro-compounds. Acta Agric Scand 6, $100-114$

Karlson, U., Dwyer, D. F., Hooper, S. W., Moore, E. R. B., Timmis, K. N. \& Eltis, L. D. (1993). Two independently regulated cytochromes P-450 in a Rhodococcus rhodochrous strain that degrade 2-ethoxyphenol and 4-methoxybenzoate. $J$ Bacteriol 175, 1467-1474.

Komagata, K. \& Suzuki, K.-I. (1987). Lipids and cell-wall analysis in bacterial systematics. Methods Microbiol 19, 161-203.
Kurup, V. P. \& Fink, J. N. (1975). A scheme for the identification of thermophilic actinomycetes associated with hypersensitivity pneumonitis. $J$ Clin Microbiol 2, 55-61.

Lee, S. T., Lee, S. B. \& Park, Y. H. (1991). Characterization of a pyridine-degrading branched Gram-positive bacterium isolated from the anoxic zone of an oil shale column. Appl Microbiol Biotechnol 35, 824-829.

Pitcher, D. G. \& Collins, M. D. (1991). Phylogenetic analysis of some LL-diaminopimelic acid-containing coryneform bacteria from human skin: description of Propionibacterium innocuum sp. nov. FEMS Microbiol Lett 84, 295-300.

Saitou, N. \& Nei, M. (1987). The neighbor-joining method: a new method for reconstructing phylogenetic trees. Mol Biol Evol 4, 406-425.

Shirling, E. B. \& Gottlieb, D. (1966). Methods for characterization of Streptomyces species. Int J Syst Bacteriol 16, 313-340.

Skerman, V. B. D. (1967). A Guide to the Identification of the Genera of Bacteria, 2nd edn. Baltimore: Williams \& Wilkins.

Suzuki, K. \& Komagata, K. (1983). Pimelobacter gen. nov., a new genus of coryneform bacteria with LL-diaminopimelic acid in the cell wall. J Gen Appl Microbiol 29, 59-71.

Tamaoka, J. \& Komagata, K. (1984). Determination of DNA base composition by reverse-phase high-performance liquid chromatography. FEMS Microbiol Lett 25, 125-128.

Tamura, T. \& Yokota, A. (1994). Transfer of Nocardioides fastidiosa Collins and Stackebrandt 1989 to the genus Aeromicrobium as Aeromicrobium fastidiosum comb. nov. Int $J$ Syst Bacteriol 44, 608-611.

Thompson, J. D., Higgins, D. G. \& Gibson, T. J. (1994). CLUSTAL $\mathrm{W}$ : improving the sensitivity of progressive multiple sequence alignment through sequence weighting, position specific gap penalties and weight matrix choice. Nucleic Acids Res 22, 4673-4680.

Wayne, L. G., Brenner, D. J., Colwell, R. R. \& 9 other authors (1987). International Committee on Systematic Bacteriology. Report of the ad hoc committee on reconciliation of approaches to bacterial systematics. Int J Syst Bacteriol 37, 463-464.

Williams, S. T., Goodfellow, M., Alderson, G., Wellington, E. M. H., Sneath, P. H. A. \& Sackin, M. J. (1983). Numerical classification of Streptomyces and related genera. J Gen Microbiol 129, 1743-1813.

Yoon, J.-H., Kim, H., Kim, S.-B., Kim, H.-J., Kim, W. Y., Lee, S. T., Goodfellow, M. \& Park, Y.-H. (1996). Identification of Saccharomonospora strains by the use of genomic DNA fragments and rRNA gene probes. Int J Syst Bacteriol 46, 502-505.

Yoon, J.-H., Rhee, S.-K., Lee, J.-S., Park, Y.-H. \& Lee, S. T. (1997). Nocardioides pyridinolyticus sp. nov., a pyridine-degrading bacterium isolated from the oxic zone of an oil shale column. Int $J$ Syst Bacteriol 47, 933-938.

Yoon, J.-H., Lee, S. T. \& Park, Y.-H. (1998a). Inter- and intraspecific phylogenetic analysis of the genus Nocardioides and related taxa based on $16 \mathrm{~S}$ rDNA sequences. Int $J$ Syst Bacteriol 48, 187-194.

Yoon, J.-H., Lee, S. T. \& Park, Y.-H. (1998b). Genetic analyses of the genus Nocardioides and related taxa based on 16S-23S rDNA internally transcribed spacer sequences. Int $J$ Syst Bacteriol 48, 641-650. 